\title{
DESCRIPTION OF THE EGG CAPSULE OF ATLANTORAJA CASTELNAUI (ELASMOBRANCHII, RAJIDAE)
}

\author{
María Cristina Oddone ${ }^{I,}{ }^{*}$, Alejo Mesa ${ }^{2}$ and Alberto Ferreira de Amorim ${ }^{3}$ \\ ${ }^{1,2}$ Universidade Estadual Paulista, Instituto de Biociências - Departamento de Ecologia \\ (Caixa Postal 199, 13506-900 Rio Claro, SP, Brasil) \\ ${ }^{3}$ Instituto de Pesca \\ (Av. Bartolomeu de Gusmão, 192, Ponta da Praia, 11030-906 Santos, SP, Brasil)
}

*cristina_oddone@yahoo.com

Skates (Rajidae) are oviparous and lay their eggs on the sea floor. Their large horny capsules are synthesized and secreted by the nidamental gland (WOURMS, 1977; WOURMS et al., 1988). The egg capsule is the tertiary cover of the egg in oviparous elasmobranchs and protects the embryo development in the sea bottom, as no parental care exists in this group. The genus Atlantoraja MENNI, 1972 is endemic to the South-western Atlantic (COMPAGNO, 2005). Atlantoraja castelnaui (MIRANDA RIBEIRO, 1907) ranges from Rio de Janeiro State (Brazil) to Argentina, and is more common in the southernmost limit of its distribution (FIGUEIREDO, 1977) where it is captured at depths of $25-220 \mathrm{~m}$ (VOOREN, 1997). In Uruguayan waters, males of this species attain sexual maturity at total lengths of 91-95 $\mathrm{cm}$ and females at 110-114 cm (ODDONE et al., 2005). Description of the egg capsules for the congeneric species A. platana and A. cyclophora are available in the literature (ODDONE et al., 2004; ODDONE, 2005). The aim of the present work is to describe the egg capsule of $A$. castelnaui, a species subjected to intense fishery and commercialization in its distributional range.

Six egg capsules of $A$. castelnaui were collected directly from the uteri of specimens caught by commercial bottom trawler from April 2005 to March 2006. These specimens were captured off the Southeast coast of Brazil, between latitudes $23^{\circ} 37^{\prime} \mathrm{S}$ and $27^{\circ} 40^{\prime} \mathrm{S}$, at a depth range of $24-120 \mathrm{~m}$. Egg capsules were fixed in $4 \%$ formalin and preserved in $70 \%$ ethanol. Data recorded from each egg capsule were: basic morphology, total length, total width, total length of anterior and posterior horns, height, thickness and width of the lateral keel, colour, configuration of the surface (texture), presence of adhesion fibrils and microscopical structure of both dorsal and ventral capsule wall, following HUBBS and ISHIYAMA, 1968; TEMPLEMAN, 1982 and GOMES and CARVALHO, 1995. Measurements were made with Vernier callipers $(0.1 \mathrm{~mm}$ precision). Detailed methodology used to analyse the microscopical structure of the egg capsule wall was presented in ODDONE et al. (2006) for Rioraja agassizi egg capsules. Differences were tested using a t-test (SOKAL and ROHLF, 1987) with a significance level of 0.05 .

A single egg capsule per oviduct was found in the present study. In the family Rajidae, one egg is deposited at a time from each oviduct, usually in pairs, during the spawning season (MUSICK and ELLIS, 2005). Freshly collected term egg capsules of $A$. castelnaui were typically rectangular with a horny process in each corner and shiny medium brown in colour (Fig. 1A), similarly to A. cyclophora and A. platana (ODDONE et al., 2004). The base of the horns, lateral margins and ventral face of the egg capsule were covered by adhesion fibrils, which facilitate the attachment to the sea bottom immediately after deposition. Such disposition of the adhesion fibrils was similar to that observed in A. cyclophora, A. platana and $R$. agassizi (ODDONE et al., 2004; 2006). The degree of development in the adhesion fibril mass and its location in the egg capsule are important to be registered because in some cases these are species-specific features (ISHIYAMA, 1958). Measurements for the six egg capsules are presented in Table 1 . The surface of both the dorsal and ventral faces were considerably smooth and in lateral view the egg capsules were keeled, varying from 5.0 to $9.0 \mathrm{~mm}$ in width and from 1.5 to $2.5 \mathrm{~mm}$ in thickness. The capsule height varied from 14.0 to $19.0 \mathrm{~mm}$. The dorsal face was convex as in the two other Atlantoraja spp. (but with the highest point situated centrally and not at the anterior capsule end) and differed from the egg capsules of $R$. agassizi (ODDONE et al., 2006), where both faces are symmetrically convex, as also noted for Sympterygia acuta, $S$. bonapartii and Psammobatis spp. (ODDONE and VOOREN, 2002; ODDONE et al., 2004) (Fig. 1B). Egg capsules ranged from 89 to $105 \mathrm{~mm}$ in total length and $70-77 \mathrm{~mm}$ in total width, and were the largest egg capsules of the genus and of the other co-occurring species for the area and depth range studied, such as R. agassizi, 

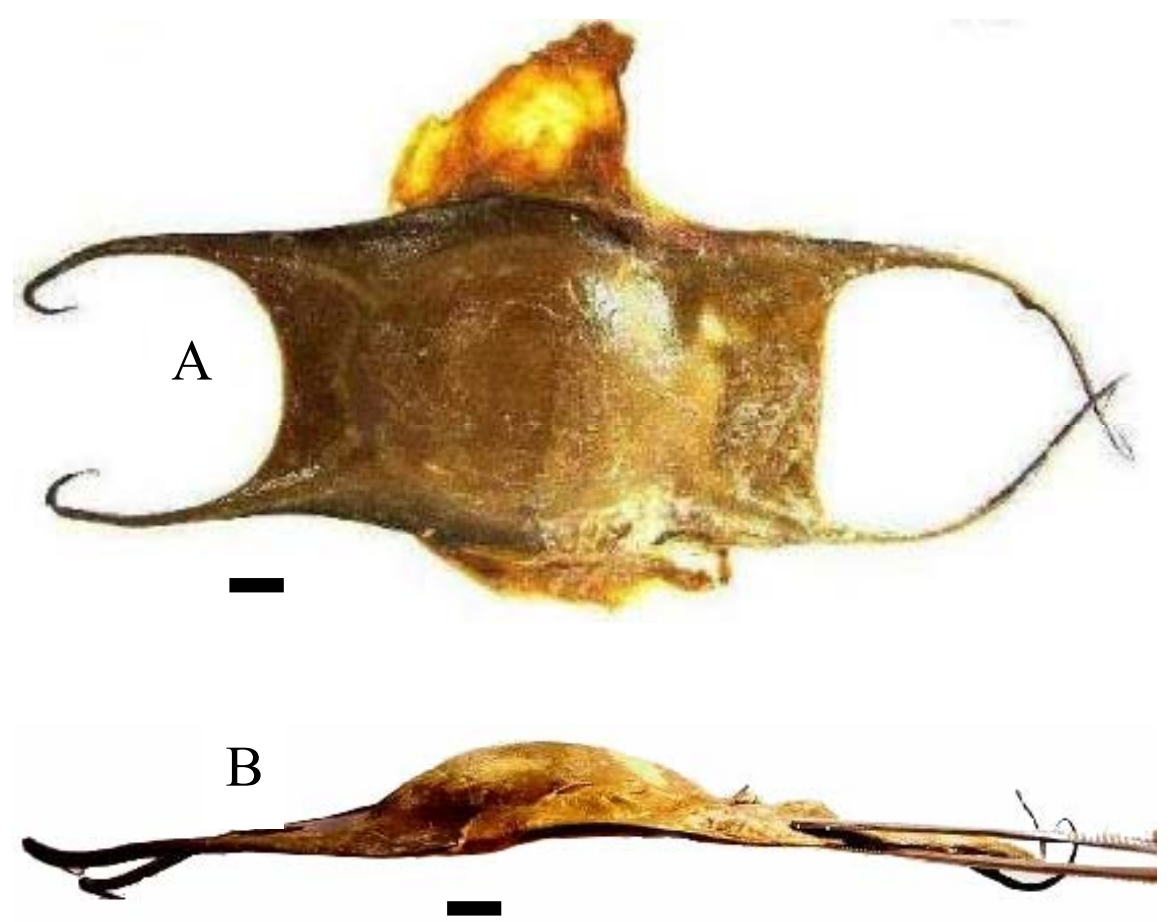

Fig. 1. Term egg capsule of Atlantoraja castelnaui in (A) upper (dorsal) and (B) lateral view. Black bar represents $1 \mathrm{~cm}$. Left side of the picture corresponds to the anterior end of the egg.

Table 1. Descriptive statistics for the variables measured $(\mathrm{mm})$ on the egg capsules of Atlantoraja castelnaui. Number (n), mean, range and standard deviation (s. d.) for the total length, total width, height, width and thickness of the lateral keel, length of anterior and posterior horns (A., P. horns) and length of anterior and posterior velum (A., P. velum).

\begin{tabular}{lcccc}
\hline \hline Variable & $\mathrm{n}$ & mean & range & s. d. \\
\hline Total length & 4 & 98.0 & $89-105$ & 7.4 \\
Total width & 5 & 73.2 & $70-77$ & 3.1 \\
Height & 3 & 16.3 & $14-19$ & 2.5 \\
Keel width & 5 & 7.4 & $5-9$ & 1.8 \\
Keel thickness & 5 & 2.1 & $1.5-2.5$ & 0.4 \\
A. horns & 3 & 60.7 & $57-65$ & 21.6 \\
P. horns & 5 & 95.0 & $85-101$ & 6.4 \\
P. velum & 5 & 20.0 & $18-21$ & 1.2 \\
A. velum & 2 & 9.0 & $6-12$ & 4.2 \\
\hline
\end{tabular}


Psammobatis spp. and Sympterygia spp. Posterior horns varied from 57.0 to $65.0 \mathrm{~mm}$ in length and were curved back towards the capsule, becoming filamentous and thread-like towards the tips. Anterior horns ranged from 85.0 to $101.0 \mathrm{~mm}$ in length and were curved inward at the tips. The difference between anterior and posterior horns length was significant $(t=-$ 7.88, $P<0.000, d f=6$ ). The posterior horn/anterior horn ratio was 1.6. Conversely, in $R$. agassizi this ratio was 1.4 and in Atlantoraja cyclophora and A. platana was 2.4 and 2.7, respectively (ODDONE et al., 2004; 2006). In S. acuta the ratio was particularly high, 15.7 , caused by the presence of extremely long tendrils instead of (posterior) horns (ODDONE and VOOREN, 2002). Egg capsules of $A$. castelnaui were laterally keeled, as also observed in A. cyclophora, A. platana and $R$. agassizi, but differed from those of Sympterygia spp., where a lateral flange exist (ODDONE and VOOREN, 2002). An anterior and a posterior velum were observed, just as in $R$. agassizi egg capsules. The posterior velum (ranging from 18.0 to $21.0 \mathrm{~mm}$ in length) was relatively straight whereas the anterior one (ranging from 6.0 to $12.0 \mathrm{~mm}$ in length) presented a concavity. Microscopically, the dorsal face wall of the egg capsule had a mean thickness of $0.32 \mathrm{~mm}$ and consisted of three layers: an external layer; markedly darker than the rest; a middle layer, colourless, light and laminated, with a number of nine superimposed lamina and an interior darker layer (Fig. 2A). In cross section, the ventral face wall had a thickness of $0.36 \mathrm{~mm}$ and presented the same three-layer pattern of one light, relatively uncoloured layer between two darker and considerably thinner external and internal layers (Fig. 2B). This pattern was the same as observed by ISHIYAMA (1958) for Japanese rajids. The surface of the egg capsule of $A$. castelnaui was relatively smooth, resembling that of $R$. agassizi. In A. cyclophora and A. platana, however, the egg capsule surface was strongly longitudinally striated and therefore, presented a rough surface (ODDONE et al., 2004). With regard to the surface configuration and the microscopical structure of the egg capsules, A. castelnaui has more features in common with $R$. agassizi than with the other Atlantoraja species.

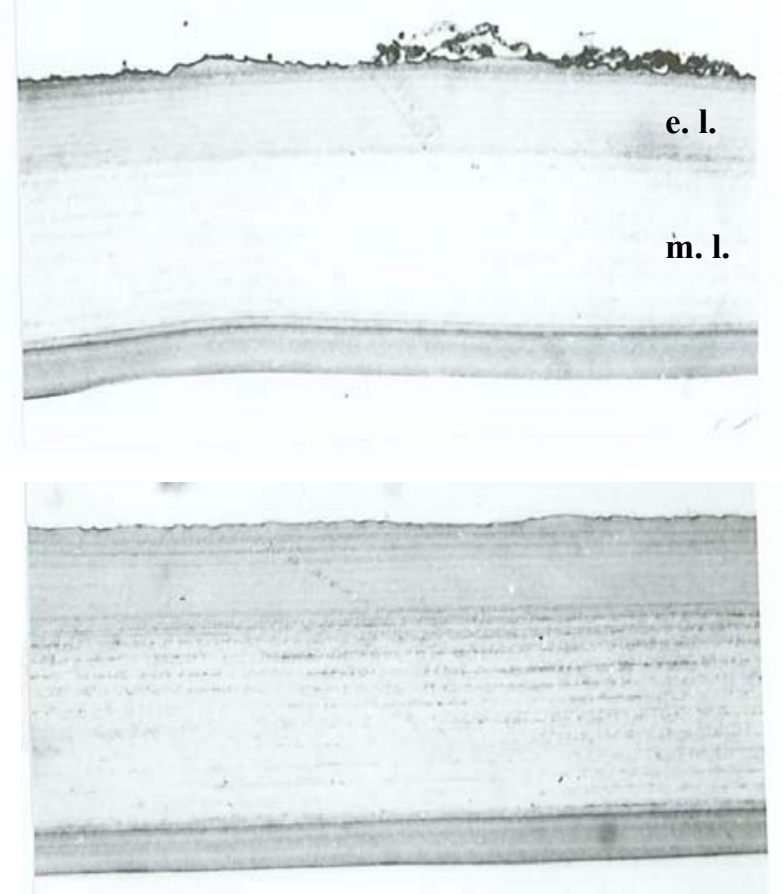

Fig. 2. Microscopical structure of the dorsal (A) and ventral (B) walls of Atlantoraja castelnaui $(100 \mathrm{X})$; e. $1 .=$ external layer; m. $1 .=$ middle layer; i. $1 .=$ inner layer. 


\section{ACKNOWLEDGEMENTS}

To P. Mancini and G. Velasco for collaborating in the skate collection and processing; skippers G. A. do Nascimento, P. Silva, E. Nascimento dos Santos, J. da Silva and W. da Silva for collecting skates on board; G. M. Souza for helping in the laboratory protocols during the assessment of the microscopical structure of the capsule; FAPESP (Fundação de Amparo à Pesquisa do Estado de São Paulo) for financing the first author's $\mathrm{PhD}$ and finally to two anonymous reviewers that refereed this manuscript making invaluable comments and suggestions.

\section{REFERENCES}

COMPAGNO, L. J. V. Checklist of living Chondrichthyes. In: HAMLETT, W. C.( Ed.).Reproductive biology and phylogeny of chondrichthyes, Sharks, batoids and chimaeras, p. 503-548. Enfield, NH: Science Publishers, 2005. $562 \mathrm{p}$.

FIGUEIREDO, J. L. Manual de Peixes Marinhos do Sudeste do Brasil. Introdução. Cações, raias e quimeras. São Paulo: Museu de Zoologia da Universidade de São Paulo. 104 p. 1977.

GOMES, U. L.; DE CARVALHO, M. R. Egg capsules of Schroederichthys tenuis and Scyliorhinus haeckelli (Chondrichthyes, Scyliorhinidae). Copeia, v. 1995, n. 1, p. 232-236, 1995.

HUBBS, C. L., ISHIYAMA, R. Methods for the taxonomic studies and description of skates (Rajidae). Copeia, v. 1968, p. 483-491, 1968.

ISHIYAMA, R. Observations on the eggs-capsules of skates of the family Rajidae, found in Japan and its adjacent waters. Bull. Mus. comp. Zool. Harvard, v. 118, n. 1, p. 1-24, 1958.

MUSICK, J. A.; ELLIS, J. K. Reproductive evolution of chondrichthyans, . In: HAMLETT, W. C., Reproductive biology and phylogeny of chondrichthyes, sharks, batoids and chimaeras, p. 45-71. Enfield, NH: Science Publishers, 2005. 562 p.

ODDONE, M. C. The microscopic structure of the egg capsules of Atlantoraja cyclophora (Elasmobranchii: Rajidae: Arhynchobatinae). Biota Neotrop., v. 5, n. 2, 1-4, 2005.

ODDONE, M. C.; VOOREN, C. M. Egg-cases and size at hatching of the south-western Atlantic skate Sympterygia acuta Garman, 1877 (Elasmobranchii, Rajidae). J. Fish Biol., v. 61, p. 858-861, 2002.
ODDONE, M. C.; MARCAL, A. S. and VOOREN, C. M. Egg capsules of Atlantoraja cyclophora (Regan, 1903) and A. platana (Günther, 1880) (Pisces, Elasmobranchii, Rajidae). Zootaxa, v. 426, p. 1-4, 2004.

ODDONE, M. C.; PAESCH, L.; NORBIS, W. Length at first sexual maturity of two species of rajoid skates, genera Atlantoraja and Dipturus (Pisces, Elasmobranchii, Rajidae), from the Southwestern Atlantic Ocean. J. Appl. Ichthyol., v. . 21, n. 1, p. 70-72, 2005.

ODDONE, M. C.; MESA, A.; AMORIM, A. F.. The egg capsule of Rioraja agassizi (Müller \& Henle, 1841) (Elasmobranchii, Rajidae), endemic to the SW Atlantic. Pan. J. aquat. . Sci., v. 1, n. 2, p. 43-48, 2006.

SOKAL, R. R.; ROHLF, F. J. Introduction to Biostatistics. Second Edition. . New York : W. H. Freeman and Company, 1987. 363 p.

TEMPLEMAN, W. Development, occurrence and characteristics of egg capsules of the thorny skate, Raja radiata, in the Northwest Atlantic . J. N. Atl. Fish. Sci.., v. 3, p. 47-56, 1982.

VOOREN, C.M. Demersal elasmobranchs. In: SEELIGER, U., ODEBRECHT, C.; CASTELLO, J.P. (Ed.). Subtropical convergence environment: the coast and the sea in the Southwestern Atlantic, p 141-146. Berlim: Springer-Verlag. 308p. 1997.

WOURMS, J. P. Reproduction and development in chondrichthyan fishes. Amer. Zool., v. 17, p. 379-410. 1977.

WOURMS, J. P.; GROVE, B. D ; LOMBARDI, J. The maternal-embryonic relationship in viviparous fishes. In: HOAR, W. S. and RANDALL, D. J. (Ed.). Fish Physiology., v. 11, p. 1-134. San Diego, Cal.: Academic Press, 1988

(Manuscript received 12 December 2006; revised 25 June 2007; accepted 05 July 2007) 